\title{
Digital Governance in Nepal
}

\author{
Gajendra Sharma \\ Department of Computer Science and Engineering, Kathmandu University \\ Dhulikhel, Nepal \\ E-mail: gajendra.sharma@ku.edu.np
}

Received: April 6, $2020 \quad$ Accepted: June 16, $2020 \quad$ Published: July 1, 2020

doi:10.5296/jmr.v12i3.17061 URL: https://doi.org/10.5296/jmr.v12i3.17061

\begin{abstract}
Digital governance or e-governance is the application of information and communication technology (ICT) for delivering government services, exchange of ICT between government and people. The government services are made available to the citizens in a convenient, efficient and transparent manner through e-governance. The purpose of this study is to highlight digital governance in Nepal during and after international pandemic COVID-19. This paper emphasizes review of different studies on development of e-government and e-governance in Nepal as well as in developing countries. The outcome of the study will be helpful for policy makers and leaders to formulate effective e-government policies and standard during crisis.
\end{abstract}

Keywords: E-government, e-governance, digital governance, COVID-19 
Introduction

2020, Vol. 12, No. 3

\section{The context}

The coronavirus disease 2019 (COVID-19), an infectious disease caused by severe acute respiratory syndrome Coronavirus 2 (SARS-CoV-2), was first identified in December 2019 in Wuhan, China. It spread across the world leading the World Health Organization to declare it a pandemic on 11 March 2020. Even the most developed countries with advanced health services like the USA, UK, France, Italy and Spain were hit hard with unprecedented rise in deaths due to COVID-19. As the symptoms of the disease are similar to those of the common flu, the initial reaction of the people from the western countries to the Wuhan situation was nonchalant. This led to people not adhering to the government's instructions for social distancing.

It is now confirmed that no disease outbreak in the world's history has traveled as far and as rapidly as COVID-19. Both the speed and the scale of the spread of the outbreak has been beyond imagining. Many countries closed their borders, banned international travels, and imposed stay at home lock downs in efforts to reduce the spread of the disease.

As it is confirmed that COVID-19 can easily transmit from human to human and given the high rate of international movement that happens on a daily basis from and to all countries, Nepal has not remained unaffected by the pandemic. Though coronavirus infected cases are 402 as of May 20, 2020 and two deaths reported so far, the lockdown has affected all spheres of life including government services. As services include the biggest number of stakeholders, the government and its institutions were not prepared to respond to the sudden crisis at first. However, some of the organization seemed to have developed their own IT infrastructures and facilities for virtual learning environment, online shopping and online information sharing which are part of digital governance.

\section{Background}

Digital governance or e-governance is the application of information and communication technology (ICT) for delivering government services, exchange of ICT between government and people. The government services are made available to the citizens in a convenient, efficient and transparent manner through e-governance. E-government is a means for governments to use the most innovative ICTs through electronic network with more convenient access to government information and services. The key benefits of e-governance include efficiency, improved services, better accessibility of public services, and transparency. The e-governance requires a considerable increase in regulation and policy making abilities, with all the expertise and opinion-shaping processes.

E-Government is defined as digital interactions between a government and citizens (G2C), government and businesses (G2B), government and employees (G2E), and between government and governments or agencies (G2G). The e-Government delivery models can be shortly summarized up as government to citizens (G2C), government to businesses (G2B), government to employees (G2E), government to governments (G2G) and citizens to governments (C2G) (Gartner, 2002). The digital interaction consists 
of governance, ICT, business process re-engineering, and e-citizen at all levels of government organizations. United Nations E-government Survey 2012 made remark that "The increasing role of e-government in promoting inclusive and participatory development has gone hand-in-hand with the growing demands for transparency and accountability in all regions of the world" (United Nations, 2012). The ultimate purpose is for lawful and efficient public governance to provide smart, inclusive and equitable growth for current and future generations. E-government generally refers to the utilization of IT, ICTs, and other web-based communication technologies to improve and develop efficiency and effectiveness of service delivery in the public sector.

\section{E-government and e-governance}

E-Government is defined as digital interactions between a government and people. E-government generally refers to the utilization of ICTs, and other web-based communication technologies to improve and develop efficiency and effectiveness of service delivery in the public sector. E-government provides the use of technologies to facilitate the government operation and the distribution of government information and services. The emergence ICT directly affects the functions and roles of government. The basic models of e-government are government to citizen, government to employees, government to government and government to business (Rossel and Finger, 2007). E-government should enable people to visit state websites to communicate and interact with employees through the internet, instant messaging, email and audio or video presentations. E-government has traditionally been understood as being centered on the operations of government, it is now thought to extend the scope by including public engagement and participation. Many countries in the world are accepting electronic government. The movement to e-government is essential for government to interact and communicate with people and business transactions.

E-government is the incessant optimization of service delivery, constituency participation and governance by transforming internal and external relationships through technology, the Internet and online media. This includes government to public, government to employee, government to business, and government to government. E-government provides the potential to bring people closer to their governments, and regardless of the type of political system in the nation, the public benefits from interactive features enabling communication and interaction between public and governments. Heeks (2008) does not agree that e-government should only have the involvement of Internet related applications, which some argue as prerequisites of e-governance.

The scope of e-governance is away from the scope of e-government. E-government in this sense is defined as a delivery of government services and information to the public using electronic means. E-governance allows people direct participation of constituents in political activities going beyond government that includes e-democracy, e-voting, and participating political activities electronically. Thus, concept of e-governance will consist of government, public participation, political parties and organizations, parliament and judiciary functions. 


\section{E-governance in developing countries}

Developing countries are lagging behind in e-government adoption compared to developed countries. During the last 10-15 years, governments from all over the world have tried to take advantage of IT and the Internet to improve governmental administration and communication with their people. IT offers the opportunity for the government to better deliver information and services and to interact with citizens, businesses, and other government stakeholders in an effective manner. The discrepancy in e-government implementation between regions in Nepal is huge due to a number of reasons, including management, infrastructure, and human factors that vary across this heterogeneous country. An e-government vision is driven by the unique setting of social, political, and economic factors and requirements. It should be noted that the vision might change for the same country upon the introduction of a new e-government strategy.

There are a large number of e-government projects in developing countries. Many of these projects are supported by international organizations, such as the United Nations and aid agencies from developed countries, or by national and regional development funds. A variety of both academic and practitioner oriented literature was found covering such projects. In Asia, there is growing recognition that e-government have the ability to improve government transparency by increasing accountability and reducing opportunities for corruption. E-government projects must focus on the social contexts into which IT is introduced. This is more important in developing countries, many of them in Asian or African countries, with great cultural differences from the western world where the technology and systems normally are designed and developed. ICT has become an increasingly important factor in the development process of nations. Major barriers can be met in the adoption and diffusion of e-government services depending on the readiness of a country in terms of ICT infrastructure and deployment (Ibrahim et al., 2011).

\section{Public participation and public service delivery}

The implementation of e-Governance has been able to enhance public service delivery, one of the core functions of governments based on quality, operations and processes. The most important influence of e-Governance on the application for learner's license is speeding up of processes and improved quality of service in terms of responsiveness and consistency. E-Governance delivers information available on government operations and public services, provides public feedback and allows direct participation by the ordinary people in decision-making (Heeks, 2008).

E-Governance is a new means of formulating and implementing policies and decisions relating to administration, services and public participation, using ICT as a tool for establishing trust in governments and enhanced transparency and public service delivery. Earlier ICT has also brought new opportunities for improved public participation in decision-making, and has therefore contributed to the establishment of the bonds between public and governments. Benefits for the government are better and more efficient services in terms of time, reducing transaction costs and improved transparency and accountability 
(Sharma et al., 2012). In the case of many advantages offered by ICTs such as speed, wider reach and cost reduction, they are now vital for the public sector, civil society organizations and for governments, which use them for intra-governmental communication as well as for providing public services and communicating withpublic.

E-Governance and e-participation are therefore significant stages in the development of online or digital government processes. A successful implication of public service delivery (PSD) requires that governments develop better capacity to handle potential hazards. Such distinct systems, with different socioeconomic and political institutional environments influence the effectiveness of collaborative service delivery management between the countries. Collaborative PSD refers to public management innovations that involve private sectors in providing public services, such as contracting out, vouchers and public-private partnerships. By assembling the advantages of both the public and private sectors, PSD is expected to generate worth for the money, managerial flexibility and customer choice and community empowerment

The E-governance ethics provides a road map for use of electronic records and electronic signatures in government and its agencies by promoting efficient delivery of government services. E-governance is a step towards better administration by facilitating transparent, speedier, responsive and non-hierarchical system of governance. Better administration leads to effective management of delivery of governmental services and this comes from managing e-governance ethical processes. The various issues concerning to e-governance ethics are summarized below:

\section{E-governance legislation}

A comprehensive legislation which may facilitate for closer cooperation between all authorities providing e-governance services. It may ensure the online service of documents, recognition to digital signature, and a freedom of choice between means of communication for submissions of documents, forms to the public administration. The legislation may cover the rights and duties of organizations involved in the development of information systems for public administration.

\section{Right to Information}

A legislation that may contain provisions on access to public information for the government bodies. It will put a legal obligation on the government staff to answer questions regarding their duties and responsibilities.

\section{Data Protection}

Data protection legislation may control the pre-conditions for the lawful use, allocation and transfer of data. The e-governance Act may specify that the data should be processed lawfully, used for specified ethical purpose, accurate and updated, secured, kept for limited period and transferred to countries where similar protections exist.

Privacy legislation

This legislation may provide a right to privacy with respect to the processing of personal 
details which entails the right to information, rectification of incorrect information and removal of unlawfully processed data. It may more be related to individual right for protection of personal data and its unlawful implication.

The online culture of disclosure holds important promises for people, including empowerment of themselves and others, the creation of communities of support around shared struggles, and the development of a broad ethical sense of responsibility with respect to privacy. Online disclosure of personal details can also yield trouble to public.

\section{Issue of trusts}

Trust in cyberspace emerges as an important issue, once the communications networks enable unprecedented level of convenience in the workplaces, homes, i.e., online shopping and e-transaction, which may affect the quality of life in a positive way. But, with sharing and reserving a large amount of information generated by and through internet, people have been engaged into the large volume of information at the internet. As a result, sometimes, people are at a loss to choose right information and safety of network security. Therefore, the issue of trusts in information, online commercial transactions and human relationships is a burning issue.

\section{Public Attitudes, Service Delivery and Bureaucratic Reform in E-Government}

The study of e-government is focused primarily on government information online, public service delivery online and on the attitudes and implication patterns of people. E-government can provide important insights into bureaucratic reform, political development, the policy-making process and the role of civil servants in information societies. The study of e-government, using an institutional perspective, provides an opportunity to observe the collision of stable practices and traditions with technological innovations, experiments and flexibility allowed to bureaucrats for smooth functioning of e-governance. E-government has the potential to build better relationships between government and the public by making interaction with citizens smoother, easier and more efficient.

The scope of e-government study can be highly strengthened and enhanced by importation of several streams of institutionalist investigation and methods. Institutional studies, establishing on a rich base of theoretical and empirical research in e-government are more difficult than the technical issues. Such study is not meant to succeed studies of information and service provision of citizen attitudes and uses of e-government, but to harmonize them by examining institutional and organizational structures and processes and their role in structuring the context within which bureaucratic reform is designed and implemented (Gajendra et al, 2012). Formal institutions also involve wide societal agreements on such matters as property rights and suitable accountability, oversight and resource allocation structures and practices. So, a multilevel integrated information system affects behavior directly and indirectly in government.

\section{Public attitude}

The impact of new technology on public-sector service delivery and public attitudes about 
government has long been controversial among political observers. The study investigates the content of e-government to locate whether it is taking advantage of the interactive features of the internet to enhance service delivery, democratic responsiveness and public outreach. Besides this, a national public opinion survey observes the capability of e-government to influence public views about government and their self-belief in the efficiency of service delivery. Implementing internet contents and public assessments, the e-government revolution has fallen short of its capacity to transform service delivery and public trust in government. It has the possibility of enhancing democratic responsiveness and increasing beliefs that government is efficient (Gajendra et al., 2012).

The interactive feature of web technology and its ability to speed communications has the potential to make governance function better. Government activities are mediated by a range of factors such as institutional arrangements, group conflict, cultural norms, budget scarcity and prevailing patterns of social and political behavior, each of which restricts technology's capability to transform politics and society. The governments are divided into competing organizations and jurisdictions that limits policy makers' ability to get bureaucrats to work together to encourage technological innovation.

\section{Bureaucratic reform}

In a democratic society, people take up multiple positions such as service recipients, taxpayers, service providers and owners of government. The public administration literature in general, treats people as inhabiting both ends of a political continuum viz. the ultimate governed and the ultimate governor. In this connection, public often provide views on policy issues that conflict with bureaucrats. Political power in a democratic society initiates from the public or citizen and is then delegated to elected officials and bureaucrats, who govern through legislation and public policy. The public play two pivotal roles in the government, the bureaucracy functions mainly as a policy framer or implementer.

Politicians and bureaucrats follow policy changes that appear to reveal inventiveness and entrepreneurship to mobilize political support. They may create to preserve long-term public interests. Bureaucratic entrepreneurship may greatly benefit the public, such as defense programs, space programs, or large-scale IT projects. Bureaucrats may demonstrate boldness when implementing new programs to increase their independence, developing the public's awareness of the innovativeness. Disclaiming the conventional perception of bureaucrats' unsatisfactory performance, Goodsell (2004) employed various sorts of evidence to protect the bureaucracy and presented bureaucrats as often being very capable, committed and mission minded. It is feasible that the government starts different policy innovations and persuades people to support the new approaches.

\section{Conceptual framework for e-Governance}

As a service provider, the state or government increasingly transforms into a regulator of outsourced or privatized services. The government policy-making will remain unaffected by changes of outsourced services. The government has a key role for the transformation of its operational activities to its public. It has to monitor the provision and the providers 
of the services, along with their quality, their prices and public accessibility to them. The globalization arises on policy levels, a global and concurrently a local level, as well as intermediate regional levels, above and below the nation-state. If the government is not merely go around by these new policy levels, it has to find ways to articulate its activities such as decision-making, operations and regulation with the actions going on at various levels. Figure 1 shows the conceptual framework of e-government on policy level.

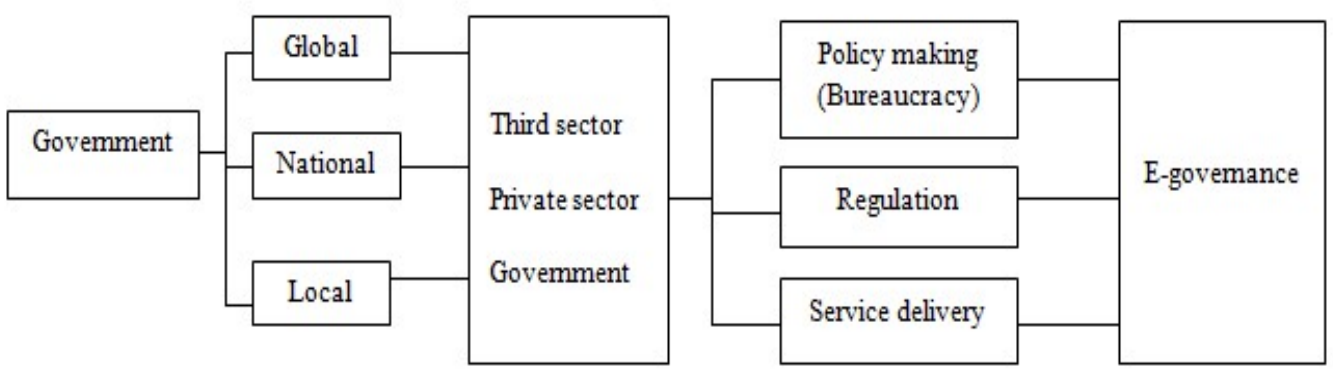

Figure 1. Conceptual Framework of E-Government

The government has three prominent functions: operations, policymaking and regulation. The globalization and liberalization policy force government to distinguish more clearly on each of these three functions. The policy-making function is increasingly divided between the global, the regional, the national and to the local levels, involving each time actors from civil society and the private sector. More or less the same can be stated as the operational function, from which the government is increasingly moving forward. The regulatory function, remains primarily at the nation-state level and involves non-state actors such as consumer organizations to a limited extent. E-governance is thus the combination of four above aspects. It is a dynamic concept, which implies the growing use of the ICTs for the three government's major functions (e.g. e-government, e-regulation and e-democracy), increasingly including non-state actors (Gajendra et. al, 2012). Taking into consideration of current literature, it can be identified three main concepts of e-governance, i.e. e-governance as customer satisfaction, e-governance as processes and interactions and e-governance as technology.

Table 1. E-Government Framework with Examples

\begin{tabular}{|l|l|}
\hline Govemment types & Examples \\
\hline $\begin{array}{l}\text { Govemment to govemment } \\
\text { Govemment to govemment } \\
\text { employees } \\
\text { Govemment to individual- } \\
\text { political }\end{array}$ & $\begin{array}{l}\text { Information flow, bilateral communication, financial transactions } \\
\text { Pay taxes online, employee benefit statements, pay dates, holiday information } \\
\text { Govemment to business- } \\
\text { public } \\
\text { Govemment to business- } \\
\text { marketplace } \\
\text { online voting } \\
\text { Online regulation, pat taxes online, receive program funds, regulatory } \\
\text { information, submitting comments online } \\
\text { Request clanification, request for proposals, online payments, marketplace for } \\
\text { venders }\end{array}$ \\
\hline Technology required: web technology, bulletin board, e-mail, electronic data interchange, public key infrastructure \\
\hline
\end{tabular}


There are different stages of e-government, which reveal the extent of technical complexity and interaction with users: information dissemination (one-way communication); two-way communication; service and financial transactions; integration and political participation (Table 1). The basic form of e-government uses IT for disseminating information, simply by posting information on the web sites. Two way communications is characterized as an interactive mode between government and public.

\section{Institutionalism Analysis of Public Participation in E-Governance}

\section{Institution}

The term 'institution is used generally in political science to indicate everything from a formal structure as a parliament to amorphous entities like social class, with other components of the socio-political universe such as law and markets also being considered as institutions. Institutions are described by their strength and their capability to influence behavior of individuals for generations. The study of human behavior can not ignore the adaptability of humans to the institutions that they generate and transform. Human behaviors will be intentional but not willful, when individuals are motivated by the values of their institutions. The sense of appropriateness also operates in less extreme situations. In majority of situations the logic of appropriateness in government institutions may be manifested through normal activities such as serving the client as well as possible, or not engaging in corruption on the job.

\section{Institutionalism}

The foundations of governments are the study of institutions. Two theoretical backgrounds behavioralism and rational choice believe that individuals act autonomously based either on socio-psychological characteristics or rational calculation of their personal value. The new institutionalism is a type with a number of specific species within it. These approaches to institutions also should be observed as harmonizing, even if the partisans of one or the other may often claim pride of place. The internal difference of the institutionalist approach indicates several supplementary things about contemporary theoretical developments.

The institutional issues affecting e-Governance can be well understood using the structure presented in Figure 2. The local government can be considered as a service provider. Public will be in touch with the local government as consumers for services such as birth/death certificates, licenses and payment of taxes. The customers approach the provider and make a payment for the service. If the quality of the service provided in the market is not enough to meet the needs of the customers, they will find for other service providers. 


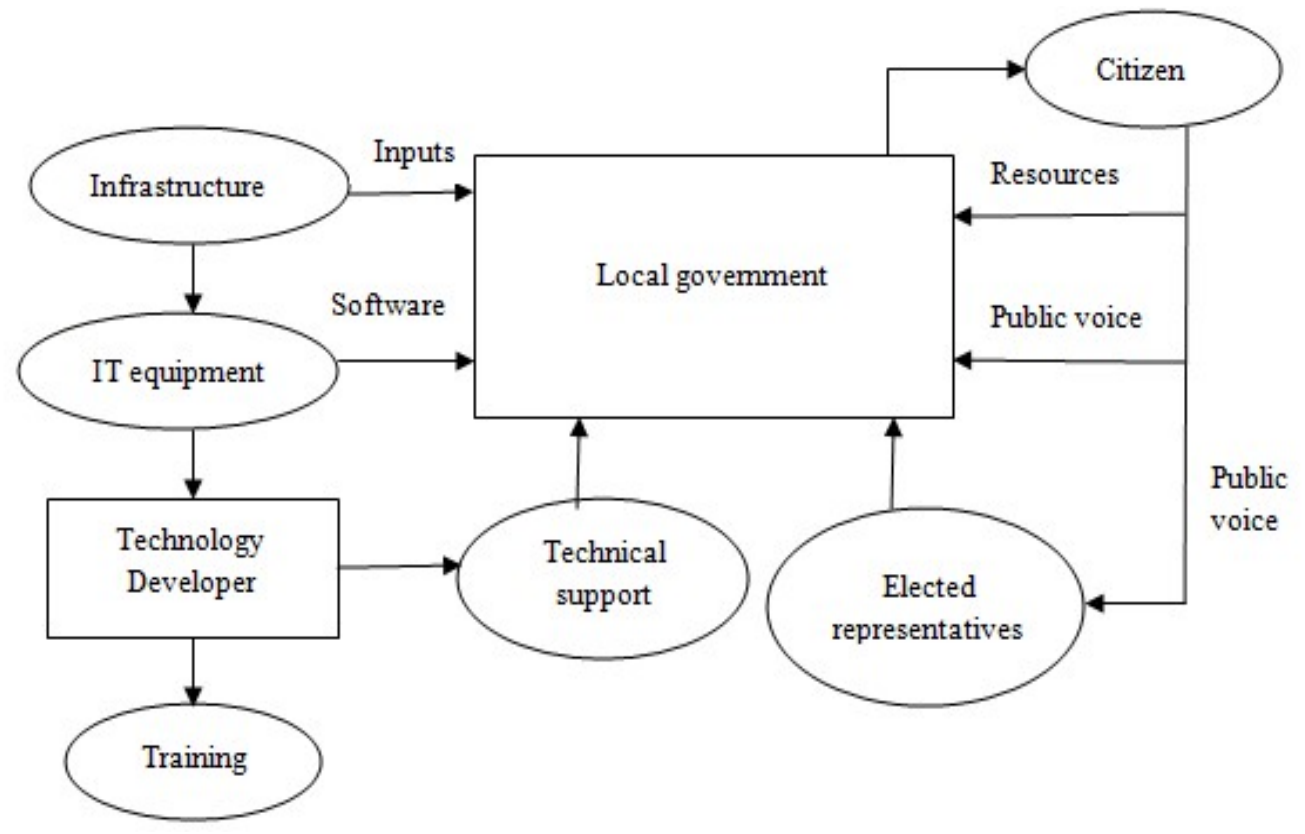

Figure 2. Framework for E-Governance and Institutional Issues

The e-governance in local governments takes place within the wider institutional environment of such governments. The rules and procedures, under which government operates, are therefore influence the pace of computerization. This will affect employees' participation in e-governance efforts. There can also be existing rules regarding the financial resources allocation, nature of record-keeping and division of responsibilities within the local government offices, and provide the ease in the implementation of e-Governance.

Online participation can activate public to engage with others within their society, express their needs and open up new ideas for responding to existing challenges. New trends of digital citizenship, principally mobile technologies, have the potential to improve the commitment of stakeholders in the political process, reversing a tendency towards disengagement, enabling better access to information and focusing services for needy people (Gajendra et al., 2012).

\section{Theoretical foundations in digital governance}

\section{Technology adoption theory}

Information technology (IT) is considered as an essential tool in enhancing the competitiveness of the economy of a country. There is consensus that IT has significant effects on the productivity of organization. These effects will only be realized if, and when, IT are widely spread and used. It is essential to understand the determinants of IT adoption. The timing and nature of innovative technology adoption are primary concerns in the perceptive of organization performance, competitiveness and efficiency growth. Technology adoption theory is related to Technology Acceptance Model (TAM). TAM is an information systems theory that describes how users come to accept and use a technology. The model suggests that when users are approached with a new technology, a 
number of factors such as perceived usefulness and perceived ease-of-use influence their decision about when and how they will use it (Davis, 1989). TAM model specifies the causal relationships between system design features, perceived usefulness, perceived ease of use, attitude toward using, and actual usage behaviour (Fig. 3). Overall, the TAM provides an informative representation of the mechanisms by which design choices influence user acceptance, infrastructure, trust level in the society, service expectations and should therefore be helpful in applied contexts for forecasting and evaluating user acceptance of information technology.

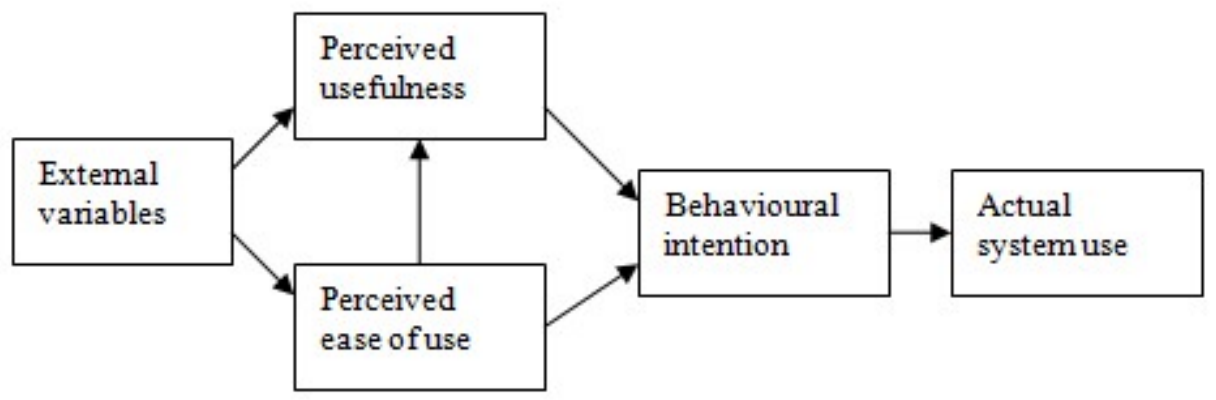

Figure 3. Technology Acceptance Model

\section{Policy network theory}

The foundations of network theory in public administration have been traced as far back as the 1930 s to early influences from anthropology and sociology. There was a similar flourishing of interest in networks within the domain of policy networks in the field of political science as well as a growing literature on social network methodology. The interest in networks and research approaches to their study began finding their way into the public administration literature. Policy networks focus on the diffusion of policy innovation, agenda setting, and institutional support for collective action. Study on public management networks emphasizes the management of complex relations between government and private actors, as well as instrumental concerns about performance. Isett et al. (2011) proposed a similar taxonomy that includes policy networks, but they also separate management networks into collaborative networks and governance networks.

Policy network theory is useful for understanding the e- government policy process in Nepal. It is helpful in exposing the idea that government decision making in Nepal takes place from the top-down. The theoretical notions developed around policy networks proved fruitful when applied to the fragmentation, interdependencies, stalemates and breakthroughs in e-government decision-making processes in Nepal.

\section{Digital Governance Model}

Fig. 4 shows the research model on e-government adoption. The conceptual model has been developed based on broad literature review. The first part of the block is relating to the motivating factors for people with the use of e-government services. The variables are infrastructure, performance expectancy, service quality, internet experience and trust. In this case these variables act as independent variables and e-government adoption acts as 
dependent variable. The variable of second block is attitude toward e-government which acts as independent variable and e-government adoption as dependant variable. The model enables to understand the public participation on e-government adoption on ethical manner.

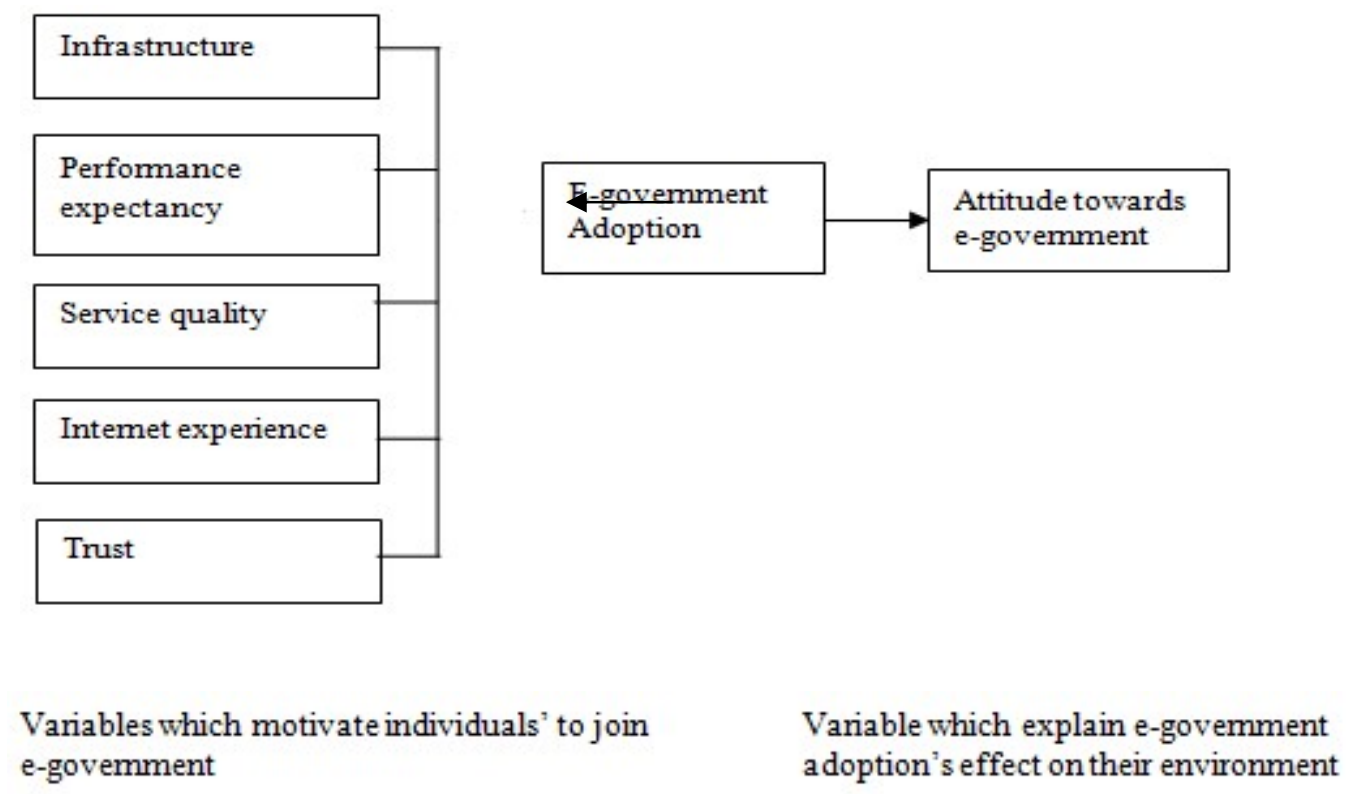

Figure 4. Digital Governance Model

\section{The concept of e-government in Nepal}

Nepal is a landlocked and underdeveloped country with population of 29.3 million. It lies in between India and China. Nepal is characterized by varied and difficult topography including highest mountain "Mount Everest". The country is still having poor literacy rate (57\% approx.) and technological culture. There is not an adequate access of government services to the people of remote and rural area of Nepal. The data processing of the country's data has started with the establishment of The National Computer Center (NCC) in1974. The involvement of private sector in the area of software development started during 1980's. The concept of outsourcing has already implemented during 1982. In the early 90's, large numbers of IT companies were emerged in capital city, Kathmandu.

ICT infrastructure and Networks are the backbone to implement e-governance. Nepal Telecom Company (NTC), the state-owned telecom operator, has been the major builder and operator of the national telecom network. NTC along with other private companies (N-Cell and Smart Telecom) provide telecommunication services in the country. They provide the services of land line phone, GSM mobile, C-phone, sky phone, sky data, internet, V-SAT and ADSL.

The Nepal government has introduced a number of policies relating to Telecommunications. The following policies have been formulated by the government that is relevant for the telecommunications sector. 
- Communications Policy (1992) 2020, Vol. 12, No. 3

- Telecommunications Policy (1999)

- Long Term Vision of Communications Sector (2002)

- Telecommunications Policy (2004)

- $\quad$ ICT Policy (2018 revised)

- Digital Nepal Framework (2019)

The Communications Policy of 1992 have liberalized telecommunications sector. It opened the door for private sectors in the telecommunications sector. Telecommunications Act was formulated in 1997 in line with the liberalization policy of 1992 establishing an independent telecom regulator. Some of the important organizations created towards ICT sector are among Ministry of Science and Technology, High Level Commission for Information Technology, and Nepal Telecom Authority. Besides these governmental institutions, a number of private organizations provide telecom services including telephone and internet services.

Government institutions are developing ICT applications separately and some of them have operated the applications for administration and public services. The following are some examples of government agencies with applications:

- Online registration of permanent account number by Inland Revenue Department.

- Personal record system by Election Commission of Nepal

- Datacenter by Supreme Court of Nepal

- Online Gate pass System by National Information Technology Center

- Online tender system by Department of Road

- Computerize citizenship in some district like Kavre, Nepal.

- Website, e-mail and internal memo management system in Ministry of Local Development

The major e-governance projects and implementing organizations in Nepal is presented in Table 2. 
Table 2. Project Components and Execution Responsibilities 2020, Vol. 12, No. 3

\begin{tabular}{|c|c|}
\hline Project components & Responsible organization \\
\hline $\begin{array}{l}\text { 1. Rural e-connectivity } \\
\qquad \begin{array}{l}\text { - Wireless broadband network } \\
\text { - Village network } \\
\text { - Telecenters }\end{array}\end{array}$ & $\begin{array}{l}\text { - Ministry of Information and } \\
\text { Communication }\end{array}$ \\
\hline $\begin{array}{l}\text { 2. Government network } \\
\qquad \text { Government information and data } \\
\text { center } \\
\text { • Government groupware }\end{array}$ & - $\quad$ Ministry of Science and Technology \\
\hline $\begin{array}{l}\text { 3. E-government application } \\
\text { • Enterprise Architecture } \\
\text { • NID/Citizen } \\
\text { • e-Gov. in Public Service } \\
\text { Commission } \\
\text { • Land Records Management } \\
\text { • Vehicle Registration Driving } \\
\text { License } \\
\text { • Online registration, online tender } \\
\text { • Personal record system and data } \\
\text { centre } \\
\text { • Digital citizenship } \\
\text { - Website and e-mail management }\end{array}$ & $\begin{array}{l}\text { - } \quad \text { High Level Commission for IT } \\
\text { - } \quad \text { Ministry of Home Affairs } \\
\text { - } \quad \text { Public Service Commission } \\
\text { - } \quad \text { Ministry of Land Reform } \\
\text { Management } \\
\text { Ministry of Land Reform } \\
\text { Management }\end{array}$ \\
\hline 4. Human resource development & - Ministry of General Administration \\
\hline
\end{tabular}

The public, private and the nonprofit organizations have been in the process of introducing ICTs for their performance in Nepal. The e-policy focuses on using e-government usually for the delivery of programs and services and the usage of information infrastructures for 
improved internal administrative procedures. In order to enhance the e-governance initiatives many legal instruments have been introduced and necessary institutional mechanism has been created. However occurrence of digital divide both at individual and institutional level is common in Nepal.

\section{Implementation of e-governance in Nepal During and after COVID-19}

E-governance has become a popular focal point of government efforts in Nepal during and after COVID-19 pandemic. Table 3 shows different challenging factors found in implementation of e-governance in Nepal. Nepal is one such least developed country that has engaged on an e-governance initiative with a number of challenges. It is arguable that e-governance has the capacity to reduce administrative and development issues but additional effort is necessary when implementing e-governance in developing or underdeveloped countries like Nepal. In this connection, e-governance helps to increase efficiency and transparency in government transactions, and facilitates democratic interaction between the government and its people.

Table 3. Factors Identified Influencing Implementation of E-Governance in Nepal During and After Pandemic

\begin{tabular}{|l|l|}
\hline Factors & Challenges of e-governance implementation \\
\hline 1. Technical factor & Energy supply, digital divide, e-readiness, privacy and security \\
\hline $\begin{array}{l}\text { 2. Education and public } \\
\text { participation }\end{array}$ & $\begin{array}{l}\text { Internet bandwidth and infrastructure, low ICT literacy and } \\
\text { education }\end{array}$ \\
\hline 3. Political factor & $\begin{array}{l}\text { Regulation and legislation, political instability, government } \\
\text { priority, frequent change of ministers and high level officials }\end{array}$ \\
\hline 4. Cultural factor & Employee resistance to change, corruption \\
\hline 5. Human resource factor & Inadequate human resource, lack of government awareness \\
\hline 6. Training on human & Public sector awareness, lack of training, limited information \\
resources & sharing and transparency \\
\hline 7. Financial factors & Investment issues, sustainability \\
\hline
\end{tabular}

The initial step in implementing e-governance in Nepal is recognizing how the egovernance program's objectives and challenges relate with the vision and strategies developed by the government. This includes business process re-engineering (BPR), which involves legislation, training, coordination, policy, as well as finance and strategy. The Nepalese BPR strategy should involve e-governance, under which high-level political leadership will be characterized by support rather than administration. Human resource development (HRD) is another major factor in the implementation of e-governance. There are some important issues related to HRD. The first issue is connected to planning of HRD. A way to develop a practical and strategic implementation plan for ICT HRD should be identified. The second issue is regarding qualified training institutions developing human resources for e-governance. 
Infrastructure is also important for information sharing among the central government and local governments, public and businesses. Village networks are one of the key factors which facilitate this connection. The promotion of village internet usage must be focused, so that people can get advantage from internet-based e-government services. The internet bandwidth cost need to be fixed as per the purchasing power of villagers. Nepal is still at an initial stage of e-governance development and implementation. In the meantime, the country has achieved some progress in ICT sector but it is not sufficient to implement e-governance throughout the nation. The popularity of ICT and e-governance has been increasing. The government is dedicated and committed to promote e-government.

\section{Conclusion}

The starting point towards e-government of is to ensure the availability of infrastructures and the knowledge supporting the enhancement of e-government, and ensuring the access of the general people to those facilities. There is a low level of adoption of e-government services in developing countries. One of the major reasons is that the citizens lack knowledge about the new e-government services. Awareness is a crucial issue for the use of e-government services. The developing countries should raise awareness throughout the country regarding their e-services through different advertising channels. The government e-services and websites should be updated on a regular basis and incorporated with online chats in which citizens can communicate with experts to gain immediate information about all e-government services during and after COVID-19. Ethical issues such as greater authentication and identification procedures are necessary for citizens to develop high levels of trust including awareness, security, and privacy of personal information.

\section{References}

Davis, F.D. (1989). Perceived Usefulness, Perceived Ease of Use, and User Acceptance of Information Technology. MIS Quarterly, 13(3), 319-340. https://doi.org/10.2307/249008

Gajendra, S., Xi, B. and Wang, Q. (2012). E-Governance: Public participation and Ethical Issues. Journal of E-governance, 35(4), 195-204. https://doi.org/10.3233/GOV-2012-0320

Gartner, A. (2002). Majority of E-Government Initiatives Fails or Falls Short of Expectations, Gartner, Inc.'s Executive Programs, San Diego, 2002.

Goodsell, C.T. (2016). The Case for Bureaucracy: A Public Administration Polemic.

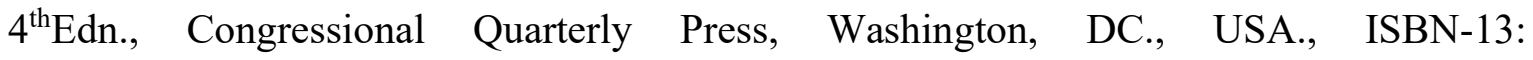
9781568029078, 2004. Pages: 208.

Heeks, R. (2008). E-government for development: Success and failure in e-government projects. Institute for Development Policy and Management (IDPM). University of Manchester. Retrieved from http://www.egov4dev.org/egovdefn.htm.

Ibrahim A. Alghamdi, R.G. and Giselle R. (2011). E-Government Readiness Assessment for Government Organizations in Developing Countries. Computer and Information Science, 4(3), 3-17. https://doi.org/10.5539/cis.v4n3p3 
Isett, K.R., Mergel, I.A. (2011). Networks in Public Administration Scholarship: Understanding Where We Are and Where We Need to Go. Journal of Public Administration Research and Theory, 21(suppl 1), i157. https://doi.org/10.1093/jopart/muq061

Park, R. (2008). Measuring Factors That Influence the Success of E-government Initiatives. Proceedings of the 41st Hawaii International Conference on System Sciences. 1530-1605/08, IEEE. https://doi.org/10.1109/HICSS.2008.244

Rossel O.R., \&Finger, M. (2007). Limits to Privatization: How to Avoid Too Much of a Good Thing. Earthscan, London, UK., ISBN-13: 9781844073399, page 414.

Sharma, G., Bao, X. and Qiang, W. (2012). E-Government: Public Participation and Ethical Issues. Journal of E-Governance, 34(2), 195-204. https://doi.org/10.3233/GOV-2012-0320

United Nations E-Government Survey. (2012). E-Government for the People, 15 March 2012, New Delhi. 